\title{
Peace, terrorism, armed conflict and war crimes
}

\author{
By Jeanine de Roy van Zuijdewijn
}

NOTE: This is the unrevised/draft version that was sent to the journal Security \& Human Rights.

The reviewers of Security and Human Rights provided feedback on the article: the revised version was accepted and published. This final version can be found here: https://doi.org/10.1163/18750230$\underline{02602011}$

For citations, please refer to the published version: Jeanine de Roy van Zuijdewijn, "Peace, terrorism, armed conflict and war crimes", Security and Human Rights, vol. 26. no. 2-4 (2015), 207-223.

\section{Peace, terrorism, armed conflict and war crimes}

Today, associating terrorism with peace sounds rather strange. Against the backdrop of Islamic State (IS) fighters slaughtering civilians in Syria and Iraq, it is challenging to see how terrorism could be connected to a situation of peace. In the past, however, this association was often made. ${ }^{1}$ Alex Schmid, possibly the most renowned terrorism scholar when it comes to defining terrorism, once said that "terrorism is the peacetime equivalent of war crimes". ${ }^{2}$ When Schmid stated this in 1992, it did not incite an academic debate about what this means for the definition of terrorism. Only in 2004, it sparked interest again when the Indian Supreme Court used this statement to define terrorism in one of its terrorism court cases. ${ }^{3}$ The academic community of terrorism scholars has not paid considerable attention to what the idea of terrorism as the peacetime equivalent of war crimes would mean for our understanding of the concept, and its possible legal implications. Currently, with an international coalition involved in a military fight against the terrorist organisation IS, it is interesting to pick up the discussion launched by Schmid in 1992 and to explore how terrorism relates to peace, armed conflict and war crimes.

This paper aims to revive the debate within terrorism studies about the relationship between peace, terrorism, as well as armed conflict, by borrowing from disciplines outside of terrorism studies that provide insight into these concepts. It thus ventures into somewhat unfamiliar terrain by leaving the field of terrorism studies, and entering the fields of Peace Studies and International Humanitarian Law (IHL). ${ }^{4}$ As the law of armed conflict, IHL helps us to see how terrorism and armed conflict relate. It is, however, less helpful when it comes to terrorism and peace. For the link between these two concepts, we need to consult Peace Studies. The aim is not to add novel academic insights to these two

\footnotetext{
${ }^{1}$ See for instance the 'waves' of terrorism as proposed in: David C. Rapoport. "The four waves of rebel terror and September 11." Anthropoetics 8.1 (2002): 1-17.

${ }^{2}$ A.P. Schmid. The Definition of Terrorism. A Study in Compliance with CTL/9/91/2207 for the

UN Crime Prevention and Criminal Justice Branch (Leiden: Center for the Study of Social Conflicts (COMT), December 1992).

${ }^{3}$ Singh v. Bihar. 2004 SOL Case No. 264, April 2, 2004, http://indiankanoon.org/doc/1537019/.

${ }^{4}$ It must be noted that the author of the paper is not educated in the field of International Humanitarian Law. However, the author noticed that this field of study is quite often unchartered territory to terrorism scholars and that it would be beneficial to be aware of the main paradigms, questions, and challenges within the field of IHL related to terrorism. For those who are interested in truly legal, academic debates on terrorism and IHL, the author would advise the work of amongst, others, Helen Duffy, Hans-Peter Gasser and Michael P. Scharf.
} 
disciplines, or to provide a thorough, rigorous overview of these fields. Rather, it wants to find interesting points of departure for those to define and study terrorism and its relationship with peace.

Somewhat paradoxically, the current debate and discourse surrounding terrorism is often void of any basic knowledge of IHL, whereas its implications are sometimes most clearly reflected and felt within this domain. This could for instance be observed in relation to the attack of IS on the city of Paris in November 2015, and the response of the international community against the threat posed by IS in the form of concerted military action, as well as in the speech by French President Hollande following the Paris Attacks which he called an "act of war". These reactions following a war paradigm raise questions about how certain acts of violence or terror, and our reaction to it, are qualified in IHL, and what the consequences might be.

The outline of the paper is as follows: it firstly provides the definition of peace as proposed by Johan Galtung, one of the most influential contributors to Peace Studies. It then briefly discusses a number of key definitions of terrorism. It points to some of the major issues of disagreement on the definitional question that need mentioning in order to understand how the concept of terrorism relates to peace and armed conflict. After this brief discussion on the definitions of peace and terrorism, it will be assessed how these concepts different converge and diverge. The second part of the paper will look at how terrorism relates to armed conflict. This part will specifically focus on the discussion on terrorism within IHL. After identifying the main issues within IHL put forward by, amongst others, Michael P. Scharf and Helen Duffy, it will look at some of the implications of dealing with terrorism under IHL. The final part of the paper will summarize how the concepts of peace, terrorism, and armed conflict relate. It also reflects upon the current fight against the Islamic State (IS), and the implications of using the war paradigm to describe this fight.

\section{1 'Negative' and 'positive' peace: origins and meaning}

When it comes to defining peace, the work of Johan Galtung, who has been called the 'father of peace studies', has played a pivotal role. Galtung was wary of only defining peace in a negating manner, merely being the absence of war or conflict. This tradition of defining peace had witnessed a centurieslong history. In fact, the origins of the word peace can be traced back to the Latin word 'pax', which via 'pais' eventually became 'peace'. Emperors and rulers were most influential in defining the term, such as the Roman Emperor Augustus who was credited for the 'Pax Romana' - the so-called Roman Peace. After a long period of violence, the first Roman Emperor went to great lengths trying to reestablish peace and security within the Roman Empire, although he did not shy away from using force to slowly continue the empire's expansion. After his death, the Pax Romana was continued for almost 200 years. The Latin connotation of the term thus meant that peace was seen as the absence of war and conflict, being some kind of power equilibrium, and proved to be rather enduring.

Galtung effectively countered this long tradition of seeing peace solely as the absence of war. His main contribution was the introduction of a distinction between 'positive peace' and 'negative peace'. Negative peace entails the more classical, Augustinian view of the term, essentially referring to the "absence of violence, absence of war" whereas positive peace encompasses a rather abstract phrase of "the integration of human society". 5 In later publications, Galtung explained how violence can either be direct or indirect, with indirect violence being a form of structural violence: poverty, inequality, discrimination, social injustice, and other related terms. To speak of positive of peace or the integration of human society, direct violence as well as this structural violence need to be absent. As

\footnotetext{
${ }^{5}$ Johan Galtung. "A structural theory of aggression." Journal of Peace Research (1964): 95-119, 2.
} 
peace essentially is a social concept - it defines the state of relations between two or more parties positive peace means more than the absence of violence or war: it means harmonious, positive relations between groups based on equality and respect. Although there have been many other contributions to the field of peace theory studies, and different definitions of peace exist, the essence although perhaps not all the particularities - of Galtung's definition has been largely accepted, and his distinction will be used in this paper.

\subsection{Defining terrorism}

When it comes to defining terrorism, it is more difficult to provide one framework or definition that has come close to the level of consensus that has been reached about a definition of peace. Terrorism scholars often start writing about terrorism by explaining that the term is highly contested, and that a universally accepted definition has yet to be agreed upon. ${ }^{6}$ Key points of disagreements arise on many aspects of the definition: who can be the acting party, what exactly is a terrorist attack, and what is the goal ${ }^{7}$ Similar to the term peace, terrorism can be traced back to at least the Roman period, descending from the verb 'terrere': to frighten. Many scholars regard the French Revolution as the first episode when terrorism was employed. "La Terreur", as it was called, was meant to both eliminate and frighten opponents of the Revolution, many of whom faced their fate under the guillotine. It was a state actor during revolutionary France that was the main executor of terror. The perception of terrorism being the domain of state actors would change over the course of time.

The context in which terrorism takes place has also widely varied over time. This is most clearly shown by American historian David Rapoport, who in his seminal article "The Four Waves of Rebel Terror and September 11" has explained how terrorism has changed its manifestations over time. The first wave of modern terrorism, as defined by Rapoport, is the anarchist wave, spearheaded by those who tried to topple the Tsarist regime in Russia. This was followed by an anti-colonial wave started from the 1920s, targeting colonial powers such as the French in Algeria. In the 1960s, a "new left wave" started in which groups such as the Rote Armee Fraktion in Germany and the Brigate Rosse in Italy fought the capitalist system and saw themselves as vanguards for the "impoverished masses" of the Third World. Since 1979, there has been a religious wave, which is very much dominated by, but not exclusively linked to, jihadist terrorism. Rapoport's waves theory helps us to understand that terrorism takes place in widely varying contexts - from "liberation struggles" against colonial powers to terrorism employed in democratic, largely non-violent countries such as West-Germany and Italy.

Traditionally, terrorism is seen as something that takes place in peacetime. Alex Schmid proposed to see terrorism as "the peacetime equivalents of war crimes" during a meeting of the UN Crime Prevention and Criminal Justice Branch in 1992. ${ }^{8}$ This definition again entered the picture in 2004 when the Supreme Court of India adopted this definition in the Singh v. Bihar court case. ${ }^{9}$ This definition is rather exceptional, as most definitions make no direct reference to either peace or conflict. An example of someone who has referred to peace is Ekaterina Stepanova. In "The Routledge Handbook of Terrorism Research", edited by Alex Schmid, she proposes an interesting categorization of sub-types of terrorism. The first category is the "'classic terrorism of peacetime' [which] is separate

\footnotetext{
${ }^{6}$ Alex Schmid. "Terrorism-the definitional problem." Case W. Res. J. Int'l L.36 (2004): 375-419.

${ }^{7}$ For a thorough overview of all these definitional issues, see: Alex P. Schmid, ed. The Routledge Handbook of Terrorism Research. Taylor \& Francis, 2011.

${ }^{8}$ Alex P. Schmid, The Definition of Terrorism, A Study in Compliance with CTL/9/91/2207 for the U.N. Crime Prevention and Criminal Justice Branch, Dec. 1992.

${ }^{9}$ Singh v. Bihar, 2004 SOL Case No. 264, April 2, 2004, http://indiankanoon.org/doc/1537019/.
} 
from any wider armed conflict, and includes 'stand-alone' left- and right-wing terrorism". ${ }^{10}$ The second type is "conflict-related terrorism" where terrorism is employed as a "tactic incorporated into asymmetric armed conflict", and can be used alongside other tactics such as guerrilla warfare. The third form is called "superterrorism", of groups with a global agenda and existential and nonnegotiable aims. ${ }^{11}$ Although the latter category is of a somewhat different nature - describing the aims rather than the context of terrorism - this categorization is rather unique in distinguishing between "peacetime" and "conflict-related" terrorism.

Most terrorism definitions do not make such explicit references to peace, or more broadly speaking, the context in which an act of terrorism takes place. The main points of discussion among terrorism scholars and other parties who define terrorism such as government agencies arise about the actors, targets, and goals of terrorism. Two examples that reflect some of the more contentious issues within this debate are the definitions proposed by Israeli terrorism scholar Boaz Ganor and the definition proposed by a governmental actor - the US State Department. Ganor wrote that "terrorism is the deliberate use of violence aimed against civilians in order to achieve political ends". ${ }^{12}$ The US State Department defines terrorism in its annual terrorism as "premeditated, politically motivated violence perpetrated against noncombatant targets by subnational groups or clandestine agents". ${ }^{13}$ Interestingly, the US State Department disqualifies state actors from being perpetrators of terrorism, an approach that is followed by many terrorism scholars. This approach, however, is different from the one used in IHL, as will be shown in the next section. Both definitions seem to suggest, albeit indirectly, that terrorism is an act conducted outside of the context of an armed conflict, or, if during an armed conflict, does not target the legitimate adversary (combatants of the other party). The specification of the targets is also a point where the two definitions differ between simply civilians (Ganor) or noncombatants (US State Department). Also, it could be argued that there is a subtle difference between being motivated by political considerations (US State Department) or aiming to achieve political goals (Ganor).

What is missing from these definitions, and what could help to distinguish terrorism from related types of political violence, is the element of fear. As shown in the categorisation of Stepanova, terrorism sometimes virtually enters the domain of other types of political violence. When terrorism is perpetrated in the context of an armed conflict, another part of the definitional question surfaces: what is the difference between an insurgency and terrorism? This becomes particularly relevant, for instance, in the current situation with regard to IS. Are they first and foremost a terrorist organisation, or could they rather be called an insurgent movement? Insurgency has been defined as "a technology of military conflict characterized by small, lightly armed bands practicing guerrilla warfare from rural base areas". ${ }^{14}$ Isabelle Duyvesteyn and Mario Fumerton have aptly explained how insurgency and terrorism can be best understood by way of differentiating between strategies and tactics. They show how terrorism could function both as a tactic and a strategy. As a tactic, it could be used in an insurgency (a strategy generally aimed at establishing overall political-military control over a territory and its population by installing competing authority systems). Terrorism could also be a strategy in

\footnotetext{
${ }^{10}$ Sarah V. Marsden and Alex P. Schmid. "Typologies of Terrorism and Political Violence”, in Alex P. Schmid, ed. The Routledge Handbook of Terrorism Research (2011), 158-200, 162.

${ }^{11}$ Idem, 162.

${ }^{12}$ Boaz Ganor. "The Relationship Between International and Localized Terrorism". Jerusalem Issue Brief 4.26 (2005).

${ }^{13} 22$ U.S. Code $\$ 2656 f$ - Annual country reports on terrorism, accessed on February 15, 2016, https://www.law.cornell.edu/uscode/text/22/2656f.

${ }^{14}$ James D. Fearon and David D. Laitin. "Ethnicity, insurgency, and civil war." American Political Science Review 97.01 (2003): 75-90, 75.
} 
itself, in which the terrorist attacks are used as a fear-inspiring tactic - not so much aimed at overall political-military control over a territory and its population - but rather aimed at compelling another actor to do or abstain from doing something by targeting a third party). ${ }^{15}$ This distinction is relevant when discussing how terrorism can be distinguished from other types of political violence. This paper, however, tries to analyse how terrorism is actually present in different contexts. To that end, this paper will from now on focus on acts of terrorism, or in other words, terrorism as a tactic, recognising that these can occur within diverse contexts. Terrorist attacks distinguish themselves from regular armed attacks by their clear focus on an indirect target and by their fear-inspiring nature. The presence of terrorism within armed conflicts is certainly not a new phenomenon, neither is the transnational nature of terrorism surprising, but it has become increasingly relevant after the attacks on 9/11 and the 'War on Terror', as well as in light of the current fight against IS in Syria and Iraq.

\subsection{Peace and terrorism: definitional relationship}

Now that we have defined peace and terrorism, we can see how these definitions relate to each other. If we follow a strict interpretation of Galtung's negative peace - being the absence of violence and war - it cannot be aligned with terrorism, which is inherently violent. This strict interpretation would mean, however, that we can never truly speak of negative peace as violence is present in virtually all communities. What negative peace rather refers to is the absence of war or armed conflict, or more frequent and intense occurrences of organized violence. In the previous paragraph, we have shown that terrorism can occur both within and outside the context of armed conflict. Before we delve deeper into the issue of terrorism within armed conflicts, we can establish that terrorism can indeed take place within a situation of negative peace. In fact, this confirms the view of terrorism being the peace-time equivalent of war crimes. Terrorism does not necessarily have to be linked to an armed conflict.

More contentious is the question to what extent terrorism can also be aligned with the definition of positive peace. As explained, positive peace is linked to ideas and values such as social justice, equality and respect. The crux here is that terrorist organisations often claim to act in response to social injustice, discrimination, and other concepts that are related to structural (indirect) violence. Extrapolating Galtung's later inclusion of "harmony" into positive peace to the discussion on terrorism would mean that these grievances do not necessarily have to be based on real facts, or even be truly experienced by the terrorists. The mere expression and references to these grievances could arguably be seen as some form of disharmony within a society. They could form proof of the absence of positive peace. This strict interpretation, again, would mean that we can almost never speak of positive peace, as there is always some extent of disharmony in most societies.

Therefore, it might be more beneficial to refrain from interpreting 'positive peace' as the complete absence of any form of disharmony or inequality, just as it has been argued that negative peace should not simply be seen as the complete absence of violence. Galtung himself wrote that 'positive peace' does allow for some 'occasional violence'. ${ }^{16}$ The question then is how much disharmony or inequality would be regarded as a "breach" of positive peace. Does this need to be widely shared, or is one individual acting against what he or she sees as inequality effectively cancelling positive peace? In some contexts where terrorism is being perpetrated, the feelings of inequality and discrimination are more widespread than in others. One example would be the case of the Liberation Tigers of Tamil Eelam (LTTE) in Sri Lanka, where a large group of the Tamil population felt discriminated by the

\footnotetext{
${ }^{15}$ Isabelle Duyvesteyn and Mario A. Fumerton. "'Insurgency and Terrorism: What's the Difference?", in: Caroline Holmqvist-Jonsäter and Christopher Coker, eds. The Character of War in the 21st Century. Routledge, 2009.

${ }^{16}$ Johan Galtung. Theories of Peace: A Synthetic Approach to Peace Thinking, International Peace Research Institute, 1967, 12.
} 
Sinhalese majority. ${ }^{17}$ Before the negative peace was effectively destroyed by the armed conflict between the LTTE and the Sri Lankan government, few would claim it was possible to speak of a situation of positive peace. A very different example would be the case of Anders Behring Breivik who killed 77 people in Norway in 2011. Although the "utopian state" of complete positive peace was not reached in Norway either, Norway would probably score high on "the scale" of positive peace, if there was to be such a scale. Although Breivik claimed he was acting to protect the "Christian values" from a "Muslim invasion", it has not been proven that the Christian population in Norway was actually being discriminated or oppressed by Muslims.

The question about the relation between positive peace and terrorism is perhaps most clear in some cases of transnational terrorism, where terrorists attack in another country. It could, theoretically, be possible that there was positive peace in the country where the attack took place, whereas the attacker came from a country where this was not the case. Think for instance about a terrorist attack aimed to drag a country into a foreign conflict. However, this example could also be problematized. When looking at transnational terrorism, it would perhaps make more sense to transnationalize the idea of positive peace as well. Peace, as war, also contains a social element, qualifying the relations between certain actors. Consequently, we also have to take into account the relations between the state or community where the attack took place and the state or community where the perpetrator(s) came from. The picture then becomes more complicated.

In sum, when looking at the definitional relationship between terrorism and peace, we can see that terrorism is mostly associated with a situation of peace, but also occurs within the context of armed conflict. Most terrorism definitions do not list any restrictions on the context in which it can occur. Galtung's definition of peace raises more questions. Terrorism as the "peacetime equivalent of war crimes" can be easily aligned with negative peace. However, when looking at positive peace, it is less clear. Theoretically, it is possible that terrorism occurs within a situation of positive peace. Whether this is also the case in practice, depends on how strictly we interpret positive peace, and how the motivations of terrorists align with these interpretations.

\subsection{Terrorism, war crimes, and armed conflict: the practice of International Humanitarian Law}

After this theoretical discussion on the definitions of peace and terrorism, this paper will show how peace and terrorism meet in (legal) practice. Firstly, it is important to note that terrorism in peacetime can be prosecuted under a number of United Nations' Terrorism Conventions, such as the 1970 Convention for the Suppression of Unlawful Seizure of Aircraft, or (international) criminal law. ${ }^{18}$ As IHL scholar Helen Duffy has shown, it would however be overly optimistic to assume that terrorism is an accessible legal concept: finding a universally accepted legal definition has been as much of a challenge as finding an academic one. ${ }^{19}$ To evade this, most bodies of law do not define terrorism an sich, but define specific forms of terrorism. The absence of an overall definition has not hindered to prosecution of particular terrorist crimes, and thus, might be less of a legal problem than is sometimes being assumed. States are continuously revising their domestic legislation to adapt to the changing nature of terrorism. More pressing issues and ambiguity in this field seems to surround terrorism in the context of the opposite of peace: an armed conflict. In order to study this, it is necessary to explain what can actually be called an armed conflict.

This is where we enter the domain of International Humanitarian Law. Shortly after the Second World War, the Geneva Conventions were adopted to guide the conduct of armed conflict and to limit

\footnotetext{
${ }^{17}$ See for instance Stanley Jeyaraja Tambiah. Sri Lanka: Ethnic fratricide and the dismantling of democracy. IB Tauris, 1986.

${ }^{18}$ See e.g. Michael P. Scharf. "Defining terrorism as the peacetime equivalent of war crimes: Problems and prospects." Case W. Res. J. Int'l L. 36 (2004): 359-374, 365.

${ }^{19}$ Helen Duffy. The 'War on Terror' and International Law, Doctoral thesis, Leiden University . E.M. Meijers Instituut, 2013, 28.
} 
civilian suffering as much as possible. These conventions - and the Additional Protocols - are all linked to the legitimate conduct of war (jus in bello), and come into force in case of an armed conflict. ${ }^{20}$ The Conventions make an important distinction between two types of armed conflict: international armed conflict (IAC) and non-international armed conflict (NIAC). The first encompasses a conflict with two or more states involved. It is important to note that a formal declaration of war does not have to be recognised by all parties, or could even be absent. ${ }^{21}$ A noninternational armed conflict occurs in the territory of a "High Contracting Party" (a state) and involves at least one or more non-governmental groups. There seems to be some disagreement about whether or not a state actor has to be involved. According to a Congressional Research Service Report prepared for the US government, "an internal conflict involves a legitimate state engaged in conflict with an armed group that has attained international personality". ${ }^{22}$ The International Committee of the Red Cross, however, asserts that the state on whose territory the conflict is taking place does not necessarily have to be involved. Still, both statements could be true in case where a foreign state is involved in a conflict with a non-state actor, on the territory of another state. However, as will be explained, this has incited a fierce debate within IHL about whether or not such a transnational conflict can still be called a NIAC.

When it comes to the case of an alleged NIAC, it must be outlined how intense the hostilities must be in order to qualify for an armed conflict instead of mere internal disturbances or skirmishes. Two criteria are usually employed to determine whether the violence can be called an armed conflict: 1) "the hostilities must reach a minimum level of intensity. This may be the case, for example, when the hostilities are of a collective character or when the government is obliged to use military force against the insurgents, instead of mere police forces". ${ }^{23}$ 2) "non-governmental groups involved in the conflict must be considered as "parties to the conflict", meaning that they possess organized armed forces. This means for example that these forces have to be under a certain command structure and have the capacity to sustain military operations". ${ }^{24}$ It is determined on a case by case basis if such criteria are met. $^{25}$

Whereas IHL applies to both IAC and NIAC, and both provide strict regulations aimed to protect the civilian population and others from disproportional or extreme suffering, there are a few important differences between the two that are worth mentioning. The most important difference is that in an IAC, captured prisoners of the opposing state are entitled to a "Prisoner of War" (POW) status, which protects them from torture and abuse, entitles them to receive humane treatment, and demands their swift release after the conflict has ended. In case of a NIAC, the combatants of the opposing, non-state actor do not enjoy such a legal status. ${ }^{26}$

IHL makes implicit as well as explicit references to terrorism. In article 33 of the Convention (IV) relative to the Protection of Civilian Persons in Time of War, it is stated that "collective penalties and

\footnotetext{
${ }^{20}$ Scharf. "Defining terrorism as the peacetime equivalent of war crimes", 363.

${ }^{21}$ International Committee of the Red Cross (ICRC). "How is the Term "Armed Conflict" Defined in International Humanitarian Law?" ICRC Opinion paper (2008), 1.

${ }^{22}$ Jennifer Elsea. "Terrorism and the Law of War: Trying Terrorists as War Criminals before Military

Commissions “, CRS Report for Congress (2011), http://fpc.state.gov/documents/organization/7951.pdf.

${ }^{23}$ International Committee of the Red Cross (ICRC). "How is the Term "Armed Conflict" Defined in International Humanitarian Law?", 3.

${ }^{24}$ Idem, p.3. and see Tamás Hoffmann. "Squaring the Circle?-International Humanitarian Law and Transnational Armed Conflicts." International Humanitarian Law and Transnational Armed Conflicts. Hague Academy of International Law (2010): 217-274.

${ }^{25}$ International Committee of the Red Cross (ICRC). Internal conflicts or other situations of violence - what is the difference for victims? (2012), https://www.icrc.org/eng/resources/documents/interview/2012/12-10-niacnon-international-armed-conflict.htm.

${ }^{26}$ International Committee of the Red Cross (ICRC). Internal conflicts or other situations of violence - what is the difference for victims?.
} 
likewise all measures of intimidation or of terrorism are prohibited". ${ }^{27}$ Furthermore, "acts of terrorism" are explicitly mentioned as one of the following acts that "shall remain prohibited at any time and in any place whatsoever" in Article 4 of one of the Additional Protocols. ${ }^{28}$ With regard to terrorism directed against the civilian population, another article states that "acts or threats of violence, the primary purpose of which is to spread terror among the civilian population are prohibited". ${ }^{29}$ Essentially, this makes it possible to prosecute terrorism during armed conflicts as a war crime. This article has been invoked, for instance, during the trial against Stanislav Galić, commander of the Bosnian Serb forces, for his acts of terrorism against the civilian population near Sarajevo. ${ }^{30}$

Thus, when it comes to the question whether or not terrorism can be executed by a state actor, IHL takes a clear position: states can be involved in terrorism, and these acts of terrorism can be prosecuted as war crimes, if it has been established that there is an armed conflict. In this sense, terrorism and war crimes clearly overlap.

\subsection{Implications of applying IHL to terrorism}

As illustrated, IHL can be used to prosecute terrorist acts, and there is no provision that prohibits this. With regard to terrorism and IHL, there are two other challenges that seem more problematic. Firstly, the nature of some of today's fights against terrorist organizations raises questions about whether this should fall under IHL. Secondly, some scholars worry that applying IHL to these cases would have serious repercussions. When it comes to the first question, part of the problem lies in the old dichotomy between IAC and NIAC. The Geneva Conventions remained rather vague about what could be called a NIAC. This question became more pressing after the attacks on 9/11 that were followed by a "Global War on Terror". This is linked to an interesting paradox that was identified by Helen Duffy, who writes that "armed groups engaged in an armed conflict are often labelled 'terrorists' (...). Conversely, one of the unusual characteristics of the so-called 'war on terror' has been the labelling of terrorist organisations as 'enemy combatants' engaged in an armed conflict'. ${ }^{31}$ This has also led to ambiguity about whether a state actor (the USA) fighting a non-state actor/terrorist organization (Al Qaeda) in the territory of a third state (Afghanistan) should be seen as an NIAC, IAC, or neither of the two. This still remains up to debate, and claims have been made to justify all three of those. ${ }^{32}$ As a result, some scholars have proposed to use the term "transnational armed conflict" to better capture the

\footnotetext{
${ }^{27}$ Convention (IV) relative to the Protection of Civilian Persons in Time of War. Geneva, 12 August 1949. Article 33, available at https://www.icrc.org/applic/ihl/ihl.nsf/4e473c7bc8854f2ec12563f60039c738/72728b6de56c7a68c12563cd0051b c40.

${ }^{28}$ Protocol Additional to the Geneva Conventions of 12 August 1949, and relating to the Protection of Victims of Non-International Armed Conflicts (Protocol II), 8 June 1977, Commentary of 1987, Fundamental Guarantees, Article 4, available at https://www.icrc.org/applic/ihl/ihl.nsf/1a13044f3bbb5b8ec12563fb0066f226/5cbb47a6753a2b77c12563cd0043a $10 \mathrm{~b}$.

${ }^{29}$ Protocol Additional to the Geneva Conventions of 12 August 1949, and relating to the Protection of Victims of Non-International Armed Conflicts (Protocol II), 8 June 1977, Article 13, available at https://www.icrc.org/applic/ihl/ihl.nsf/4e473c7bc8854f2ec12563f60039c738/a366465e238b1934c12563cd0051e $\underline{8 \mathrm{a} 0}$.

${ }^{30}$ Laura Paredi, "The War Crime of Terror: An Analysis of International Jurisprudence”, ICD Brief 11 (2015), http://www.internationalcrimesdatabase.org/upload/documents/20150610T161554Laura\%20Paredi\%20ICD\%20Brief final.pdf.

${ }^{31}$ Duffy. The 'War on Terror' and International Law, 309.

${ }^{32}$ Hoffmann. "Squaring the Circle?", 9.
} 
non-state, international nature of such a conflict. ${ }^{33}$ The US government made attempts to sell the "War on Terror" as an IAC, but this has not been legally established..$^{34}$

Against the backdrop of the current fight against IS, there might be legal arguments to revise this idea of this particular fight not being an IAC or NIAC. Duffy mentions that there is an important exception to the legal common practice of seeing an IAC only as a conflict between states. This is when the actor exercises 'quasi-state' functions. ${ }^{35}$ Whereas this was arguably not applicable to the case of Al Qaeda and the 'War on Terror', this might be regarded differently in the case of IS. IS has been an 'extraordinary' terrorist organisation in the sense that it has been able to conquer, control and establish effective authority over large swaths of territory. It has also increasingly developed a state-like structure, expanding its bureaucracy, with several "governmental bodies", such as ministries. It has for instance opened ministries of agriculture, public health, and education, which are only indirectly related to the conflict. ${ }^{36}$

Also, some of the reasons why the fight against Al Qaeda could not be seen as a NIAC, appear also less relevant in the case of IS. When Duffy discussed whether or not Al Qaeda met the criteria to be seen as an actor in a NIAC, she doubts this was the case. Criteria are, amongst others, "scope and membership, sufficient organisation and structure, and the capability of abiding by the rules of IHL". ${ }^{37}$ IS would score a lot better on these criteria than Al Qaeda did. For instance, it has been reported that IS members need to fill out registration forms upon desiring to join the group, which would make the question proving group membership much easier. ${ }^{38}$ Also, IS seems to be more centralised than $\mathrm{Al}$ Qaeda, and members - when referring to the Iraqi and Syrian battle zone - can be more easily recognised. This would arguably also mean that the leadership of IS should - in theory - be able to control its members and to make sure they abide to certain IHL rules, which would could turn them into an actor in a NIAC.

The second point of contention within IHL related to terrorism and the fight against terrorism are the alleged repercussions of calling a fight with and against a terrorist group an armed conflict. The US, for instance, has claimed that Al Qaeda members are "unlawful enemy combatants", who do not fall under the protection of the Geneva Conventions. ${ }^{39}$ However, calling the War on Terror an IAC would be seen as a serious upgrade for the status of the terrorists. They would first of all be seen as legal combatants, and secondly, theoretically be entitled to a Prisoner of War-status upon capture. Also, the articles in the Geneva Conventions and Additional Protocols outlaw most attacks on civilians, but do permit attacks on combatants. This latter point, in fact, could justify attacks by terrorist organizations on military targets. These reasons have motivated Michael Hoffmann to argue that there is a clear "misfit" between current IHL and the characteristics of today's terrorist groups. ${ }^{40}$ It might be difficult to argue that these cases could qualify as a NIAC, but there is even more reluctance to call it an IAC.

\footnotetext{
${ }^{33}$ Idem, 29.

${ }^{34}$ Marko Milanovic. "Lessons for human rights and humanitarian law in the war on terror: comparing Hamdan and the Israeli Targeted Killings case." International Review of the Red Cross 89.866 (2007): 373-393, 378.

${ }^{35}$ Duffy. The 'War on Terror' and International Law, 351.

${ }^{36}$ Daan Weggemans, Edwin Bakker and Ruud Peeters. Bestemming Syrië: Een exploratieve studie naar de leefsituatie van Nederlandse 'uitreizigers' in Syrië. Universiteit Leiden/Universiteit van Amsterdam (2016), 3940.

${ }^{37}$ Duffy. The 'War on Terror'and International Law, 354.

${ }^{38}$ Ewen MacAskill. "Isis document leak reportedly reveals identities of 22,000 recruits", The Guardian (March 9, 2016), http://www.theguardian.com/world/2016/mar/09/isis-document-leak-reportedly-reveals-identitiessyria-22000-fighters.

${ }^{39}$ Milanovic, "Lessons for human rights and humanitarian law in the war on terror", 378.

${ }^{40}$ Michael H. Hoffman. "Terrorists Are Unlawful Belligerents, Not Unlawful Combatants: A Distinction with Implications for the Future of International Humanitarian Law." Case W. Res. J. Int'l L. 34 (2002): 227-230, 229.
} 
As a result, it often remains rather vague and ambiguous how a certain fight against a terrorist organization qualifies under IHL. This legal ambiguity is recognized as a serious issue by many IHL scholars, as it is necessary that any fight against terrorist organizations is also clearly and transparently bounded by the rule of law.

In sum, IHL provides sufficient ground to prosecute terrorist attacks ${ }^{41}$, regardless of who perpetrates the act. The most pressing questions with regard to IHL and terrorism seem to be as follows: should we qualify some of the military attempts to counter terrorism as armed conflict guided by IHL, and if so, are these international or non-international armed conflicts? If IHL is applicable, this might have legal repercussions for the terrorists, effectively upgrading their status.

\section{Concluding remarks}

This paper wishes to end with a some final reflections against the backdrop of today's fight against the Islamic State, and raise some questions about the current war paradigm. After IS's rapid conquest of large parts of Iraq in 2014, the US-led Combined Joint Task Force - Operation Inherent Resolve was set up to coordinate the fight against IS. In November 2015, a group of terrorists linked to IS perpetrated a terrorist attack on the territory of one of the coalition partners, France, killing 130 citizens. Immediately after the attack, French President Hollande called the attacks an "act of war" and said France was currently confronted with "war". ${ }^{42}$ This was a clear move away from what other European leaders had declared in their speeches after the attacks in Madrid (2004) or London (2005), where the war paradigm was not being mentioned. Hollande's speech sounded more familiar to the speech by US President George Bush after the 9/11 attacks, where he stated that the "enemies of freedom" had perpetrated an "act of war" against the US, and thus, the US was forced to start a "war on terror". "Hollande referred to IS (Daesh, as he said) as a "terrorist army" rather than a terrorist organization. Although these statements might invoke a strong moral reaction, their accurateness and desirability could be questioned.

First of all, saying that this is an act of war, in legal terms, implicitly means that you recognize there is an ongoing armed conflict between you and that party. An "act of war" is any act that is occurring within a war, and thus, does not have to be a war crime such as terrorism would be. In other words, an act of war can be perfectly legal within the framework of IHL, which is probably not what Hollande hoped to convey when he called this attack an act of war.

Secondly, calling this a war also means that clarity is needed about the nature of this war. Does it fall under IHL, and which provisions will guide it? Also, referring to IS as a terrorist army leaves the impression that the group really is a state-like organization, and it has gone a long way to present itself like that. If this mean we would see it as an international armed conflict, the earlier mentioned repercussions come into play: IS would be recognized as a legitimate actor in this conflict, and IS militants would thus qualify as lawful combatants. This would mean that they - as well as France and the other states involved in the international coalition against IS - have to obey to the provisions outlined in IHL.

This would, in a legal sense, prohibit attacks like the one in Paris. Unfortunately, there is little reason to think IS would restrict its actions as outlined in IHL. Rather, it could (ab)use IHL to find justifying

\footnotetext{
${ }^{41}$ For a more thorough overview of how IHL relates to prosecuting terrorism, see Christophe Paulussen. "Testing the Adequacy of the International Legal Framework in Countering Terrorism: The War Paradigm." (2012), http://www.icct.nl/download/file/ICCT-Paulussen-Legal-Framework-for-Counter-Terrorism-August2012.pdf.

42 “President Hollande calls Paris attacks an 'act of war' - video", The Guardian (November 14, 2015), http://www.theguardian.com/world/video/2015/nov/14/president-hollande-paris-attacks-act-of-war-video.

43 “Text of George Bush's speech", The Guardian (September 21, 2001), http://www.theguardian.com/world/2001/sep/21/september11.usa13.
} 
grounds for targeting military personnel and facilities in France and of other parties involved in the conflict. Whereas acts of terrorism and other war crimes are outlawed, attacks against military personnel - generally speaking - are not. Also, in case of an international armed conflict, captured militants IS would qualify as Prisoners of War, which would mean they would have to be released after the cessation of hostilities. ${ }^{44}$

Hollande's statements do not only raise question about their legal meaning and implications, they sent out the wrong signals to the terrorists and, paradoxically, could advocate the use of terrorism. On the one hand, these statements might serve as sense- and meaning-making tools, explaining to the French population what has happened and what this means for the country. Another positive aspect might be that Hollande speaks of a strong and determined France; a France that is not afraid, which could help the domestic morale. On the other hand, there is no greater sign of recognition for a terrorist organization than a Great Power declaring that you, with your "army", have been able to deal a devastating blow to them, and are at war.

Terrorists typically aim for an overreaction that will reinforce their own rhetoric of being oppressed or under attack. Osama bin Laden had declared war on the USA already in 1996, but it took an attack like the one on 9/11 to finally see the USA "accepting" this declaration, which far from disappointed Bin Laden. It has also proven rather difficult to win a "war against terrorism". Although terrorist organizations can be defeated militarily, this would not necessarily mean that their ideology has been defeated as well. Contrarily, it is often strengthened by the same efforts, as we have seen in the past fifteen years. Thus, when speaking about terrorism, peace, and armed conflict or war, it might be useful to refrain from introducing the 'war paradigm'. The link between armed conflict and terrorism, however, seems ever more present today. Therefore, it is high time to reopen the debate that was started by Alex Schmid in 1992 on how terrorism, peace, and armed conflict relate.

\footnotetext{
${ }^{44}$ Hoffman. "Terrorists Are Unlawful Belligerents, Not Unlawful Combatants, 230.
} 


\section{Bibliography}

22 U.S. Code $\$ 2656 f$ - Annual country reports on terrorism, accessed on February 15, 2016, https://www.law.cornell.edu/uscode/text/22/2656f.

Convention (IV) relative to the Protection of Civilian Persons in Time of War. Geneva, 12 August 1949. Article 33, available at https://www.icrc.org/applic/ihl/ihl.nsf/4e473c7bc8854f2ec12563f60039c738/72728b6de56c7a68c12563cd0051b $\underline{\mathrm{c} 40 .}$.

Duffy, Helen. The 'War on Terror' and International Law, Doctoral thesis, Leiden University . E.M. Meijers Instituut, 2013.

Duyvesteyn, Isabelle and Mario A. Fumerton. "'Insurgency and Terrorism: What's the Difference?', in: Caroline Holmqvist-Jonsäter and Christopher Coker, eds. The Character of War in the 21st Century. Routledge 2009.

Elsea, Jennifer. "Terrorism and the Law of War: Trying Terrorists as War Criminals before Military Commissions“, CRS Report for Congress (2011), http://fpc.state.gov/documents/organization/7951.pdf.

Fearon, James D., and David D. Laitin. "Ethnicity, insurgency, and civil war." American Political Science Review 97.01 (2003): 75-90.

Galtung, Johan. "A structural theory of aggression." Journal of Peace Research (1964): 95-119.

Galtung, Johan. Theories of Peace: A Synthetic Approach to Peace Thinking, International Peace Research Institute, 1967.

Ganor, Boaz. "The Relationship Between International and Localized Terrorism". Jerusalem Issue Brief 4.26 (2005).

Hoffman, Michael H. "Terrorists Are Unlawful Belligerents, Not Unlawful Combatants: A Distinction with Implications for the Future of International Humanitarian Law." Case W. Res. J. Int'l L. 34 (2002): 227-230.

Hoffmann, Tamás. "Squaring the Circle?-International Humanitarian Law and Transnational Armed Conflicts." International Humanitarian Law and Transnational Armed Conflicts. Hague Academy of International Law (2010): 217-274.

International Committee of the Red Cross (ICRC). "How is the Term "Armed Conflict" Defined in International Humanitarian Law?" ICRC Opinion paper (2008).

International Committee of the Red Cross (ICRC). Internal conflicts or other situations of violence - what is the difference for victims? (2012), https://www.icrc.org/eng/resources/documents/interview/2012/12-10-niac-noninternational-armed-conflict.htm.

MacAskill, Ewen. "Isis document leak reportedly reveals identities of 22,000 recruits", The Guardian (March 9, 2016), http://www.theguardian.com/world/2016/mar/09/isis-document-leak-reportedly-reveals-identities-syria22000-fighters.

Marsden, Sarah V. and Alex P. Schmid. "Typologies of Terrorism and Political Violence”, in Alex P. Schmid, .ed. The Routledge Handbook of Terrorism Research, 2011, 158-200.

Paredi, Laura. "The War Crime of Terror: An Analysis of International Jurisprudence”, ICD Brief 11 (2015), http://www.internationalcrimesdatabase.org/upload/documents/20150610T161554Laura\%20Paredi\%20ICD\%20Brief_final.pdf.

Paulussen, Christophe. "Testing the Adequacy of the International Legal Framework in Countering Terrorism: The War Paradigm." (2012), http://www.icct.nl/download/file/ICCT-Paulussen-Legal-Framework-for-CounterTerrorism-August-2012.pdf. 
"President Hollande calls Paris attacks an 'act of war' - video", The Guardian (November 14, 2015), http://www.theguardian.com/world/video/2015/nov/14/president-hollande-paris-attacks-act-of-war-video.

Protocol Additional to the Geneva Conventions of 12 August 1949, and relating to the Protection of Victims of Non-International Armed Conflicts (Protocol II), 8 June 1977, Article 13, available at https://www.icrc.org/applic/ihl/ihl.nsf/4e473c7bc8854f2ec12563f60039c738/a366465e238b1934c12563cd0051e $\underline{8 \mathrm{a} 0}$.

Protocol Additional to the Geneva Conventions of 12 August 1949, and relating to the Protection of Victims of Non-International Armed Conflicts (Protocol II), 8 June 1977, Commentary of 1987, Fundamental Guarantees, Article 4, available at https://www.icrc.org/applic/ihl/ihl.nsf/1a13044f3bbb5b8ec12563fb0066f226/5cbb47a6753a2b77c12563cd0043a $10 \mathrm{~b}$.

Rapoport, David C. "The four waves of rebel terror and September 11." Anthropoetics 8.1 (2002): 1-17.

Scharf, Michael P. "Defining terrorism as the peacetime equivalent of war crimes: Problems and prospects." Case W. Res. J. Int'l L. 36 (2004): 359-374.

Schmid, A.P. The Definition of Terrorism. A Study in Compliance with CTL/9/91/2207 for the UN Crime Prevention and Criminal Justice Branch (Leiden: Center for the Study of Social Conflicts (COMT), December 1992).

Schmid, Alex. "Terrorism-the definitional problem." Case W. Res. J. Int'l L.36 (2004): 375-419.

Schmid, Alex P., ed. The Routledge Handbook of Terrorism Research. Taylor \& Francis, 2011.

Singh v. Bihar, 2004 SOL Case No. 264, April 2, 2004, http://indiankanoon.org/doc/1537019/.

Tambiah, Stanley Jeyaraja. Sri Lanka: Ethnic fratricide and the dismantling of democracy. IB Tauris, 1986.

"Text of George Bush's speech", The Guardian (September 21, 2001), http://www.theguardian.com/world/2001/sep/21/september11.usa13.

Weggemans, Daan, Edwin Bakker and Ruud Peeters. Bestemming Syrië: Een exploratieve studie naar de leefsituatie van Nederlandse 'uitreizigers' in Syrië. Universiteit Leiden/Universiteit van Amsterdam (2016). 